\title{
Three-step in vitro maturation culture of bovine oocytes imitating temporal changes of estradiol-17 $\beta$ and progesterone concentrations in preovulatory follicular fluid
}

\author{
Minami Matsuo, Kazuma Sumitomo, Chihiro Ogino, Yosuke Gunji, Ryo Nishimura, and \\ Mitsugu Hishinuma \\ Laboratory of Theriogenology, Joint Department of Veterinary Medicine, Faculty of Agriculture, Tottori \\ University, 4-101 Koyama-minami, Tottori 680-8553, Japan \\ Correspondence to: Mitsugu Hishinuma (mhishi@muses.tottori-u.ac.jp)
}

Received: 5 March 2017 - Revised: 14 July 2017 - Accepted: 24 July 2017 - Published: 17 October 2017

\begin{abstract}
The objective of the article is to evaluate the effect of three-step in vitro maturation (IVM) culture system imitating estradiol-17 $\beta\left(\mathrm{E}_{2}\right)$ and progesterone $\left(\mathrm{P}_{4}\right)$ concentrations in preovulatory follicles on in vitro bovine embryo production. The cumulus-oocyte complexes (COCs) were collected from follicles ( 2 to $8 \mathrm{~mm}$ in diameter) of bovine ovaries obtained from a local slaughterhouse. For IVM, the COCs were cultured for $22 \mathrm{~h}$ in a three-step system: (1) culture in medium 199, containing $700 \mathrm{ng} \mathrm{mL}^{-1} \mathrm{E}_{2}$ and $50 \mathrm{ng} \mathrm{mL}^{-1} \mathrm{P}_{4}$, for $5 \mathrm{~h}$, followed by the medium containing $150 \mathrm{ng} \mathrm{mL}^{-1} \mathrm{E}_{2}$ and $150 \mathrm{ng} \mathrm{mL}^{-1} \mathrm{P}_{4}$ for $11 \mathrm{~h}$, and then the medium containing $20 \mathrm{ng} \mathrm{mL}^{-1} \mathrm{E}_{2}$ and $300 \mathrm{ng} \mathrm{mL}^{-1} \mathrm{P}_{4}$ for $6 \mathrm{~h}$ (EP group); (2) culture in the medium containing $700 \mathrm{ng} \mathrm{mL}^{-1} \mathrm{E}_{2}$ for $5 \mathrm{~h}$, followed by the medium containing $150 \mathrm{ng} \mathrm{mL}^{-1} \mathrm{E}_{2}$ for $11 \mathrm{~h}$, and then the medium containing $20 \mathrm{ng} \mathrm{mL}^{-1}$ $\mathrm{E}_{2}$ for $6 \mathrm{~h}$ (E group); or (3) culture in the medium containing $50 \mathrm{ng} \mathrm{mL}^{-1} \mathrm{P}_{4}$ for $5 \mathrm{~h}$, followed by the medium containing $150 \mathrm{ng} \mathrm{mL}^{-1} \mathrm{P}_{4}$ for $11 \mathrm{~h}$, and then the medium containing $300 \mathrm{ng} \mathrm{mL}^{-1} \mathrm{P}_{4}$ for $6 \mathrm{~h}$ (P group). The COCs were cultured in the medium containing $1000 \mathrm{ng} \mathrm{mL}^{-1} \mathrm{E}_{2}$ for $22 \mathrm{~h}$ (control group). After IVM, the COCs were co-incubated with sperm and further cultured. At $48 \mathrm{~h}$ after insemination, the cleavage rate of embryos was not different among the groups. At $192 \mathrm{~h}$ after insemination, the blastocyst formation rate of EP group was significantly higher than that of the other groups. The total cell number of blastocysts did not differ among the groups. In conclusion, these results demonstrate that the three-step IVM culture system of bovine oocytes imitating temporal changes of $\mathrm{E}_{2}$ and $\mathrm{P}_{4}$ concentrations in preovulatory follicular fluid improves the developmental potential of embryos in vitro.
\end{abstract}

\section{Introduction}

The development of techniques for the effective production of bovine preimplantation embryos from oocytes matured and fertilized in vitro is important for embryo transfer and basic scientific research. Temperature (Lenz et al., 1983), oxygen concentration (Hashimoto et al., 2000), nutrients (Takahashi and First, 1992; Kim et al., 1993) and hormones (Fukui et al., 1982; Silva and Knight, 2000; Beker et al., 2002; Mingoti et al., 2002) during in vitro maturation (IVM) culture are considered as factors to improve in vitro development of bovine oocytes. However, developmental rate of bovine oocytes to blastocyst in vitro was still lower than that of in vivo (Leibfried-Rutledge et al., 1987; Rizos et al., 2002). Recently, simulated physiological oocyte maturation (SPOM) system using an inhibitor of phosphodiesterase and activator of adenylate cyclase (cAMP-mediated pre-IVM) was proposed to mimic some characteristics of bovine oocyte maturation in vivo (Albuz et al., 2010). However, effectiveness of the SPOM system on bovine embryo production has not been established (Guimarães et al., 2015). 
Change in steroid hormone concentration in preovulatory follicles is thought to relate oocyte maturation (Moor et al., 1980; Dieleman et al., 1983; Wrenzycki and Stinshoff, 2013). Ovulation occurs at $24 \pm 1.4 \mathrm{~h}$ after luteinizing hormone (LH) surge in cattle (Dieleman et al., 1983). Estradiol-17 $\beta\left(\mathrm{E}_{2}\right)$ concentration of bovine follicular fluid decreased from $798-1648 \mathrm{ng} \mathrm{mL}^{-1}$ at $0-5 \mathrm{~h}$ before $\mathrm{LH}$ surge to $180-256 \mathrm{ng} \mathrm{mL}^{-1}$ at $6-15 \mathrm{~h}$ after $\mathrm{LH}$ surge, and to 80 $125 \mathrm{ng} \mathrm{mL}^{-1}$ at $20-23 \mathrm{~h}$ after LH surge, estimated as just before ovulation (Dieleman et al., 1983; Fortune and Hansel, 1985; Hansen et al., 1988; Li et al., 2007). Simultaneously, progesterone $\left(\mathrm{P}_{4}\right)$ concentration of bovine follicular fluid increased from $50-122 \mathrm{ng} \mathrm{mL}^{-1}$ at $0-5 \mathrm{~h}$ before $\mathrm{LH}$ surge to $41-150 \mathrm{ng} \mathrm{mL}^{-1}$ at $6-15 \mathrm{~h}$ after $\mathrm{LH}$ surge, and to 280 $475 \mathrm{ng} \mathrm{mL}^{-1}$ at $20-23 \mathrm{~h}$ after LH surge (Dieleman et al., 1983; Fortune and Hansel, 1985; Hansen et al., 1988; Li et al., 2007; Fortune et al., 2009).

In many studies, supplementation of $1000 \mathrm{ng} \mathrm{mL}^{-1} \mathrm{E}_{2}$ to the IVM medium was effective for resumption of meiosis and promotion of maturation of bovine oocytes (Fukui et al., 1982; Fukushima and Fukui, 1985; Younis et al., 1989; Beker et al., 2002). $\mathrm{P}_{4}$ was added to the IVM medium for bovine oocytes at a concentration of $50-5000 \mathrm{ng} \mathrm{mL}^{-1}$, and various results were reported on embryo production (Silva and Knight, 2000; Aparicio et al., 2011; Syoji et al., 2014). Concentration of $\mathrm{P}_{4}$ in the IVM medium was fixed during the culture except with Syoji et al. (2014), and $\mathrm{E}_{2}$ and $\mathrm{P}_{4}$ concentrations in preovulatory follicular fluid were not considered for medium preparation in the previous studies. In porcine embryo production, three-step IVM culture system was developed to mimic hormonal changes observed in vivo (Kawashima et al., 2008). Porcine oocytes were pre-cultured with follicle-stimulating hormone (FSH) and $\mathrm{E}_{2}$ for $10 \mathrm{~h}$, after which time $10 \mathrm{ng} \mathrm{mL}^{-1} \mathrm{P}_{4}$ was added for another $10 \mathrm{~h}$. The oocytes were then transferred to fresh medium containing LH, epidermal growth factor (EGF) and $100 \mathrm{ng} \mathrm{mL}^{-1} \mathrm{P}_{4}$. Similar culture system could be applied to bovine IVM, although duration of bovine IVM culture is about half compared to porcine IVM culture. Therefore, temporal changes of $\mathrm{E}_{2}$ and $\mathrm{P}_{4}$ concentration to mimic changes in preovulatory follicular fluid should be examined for IVM of bovine oocytes.

The objective of the present study was to evaluate the effect of three-step IVM culture system imitating temporal changes of steroid hormone concentrations in preovulatory follicular fluid on bovine embryo production in vitro. Bovine oocytes were cultured in the IVM medium containing various concentrations of $\mathrm{E}_{2}$ and $\mathrm{P}_{4}$ for $22 \mathrm{~h}$, co-incubated with sperm and further cultured to examine developmental competence to blastocyst.

\section{Materials and methods}

\subsection{Collection of cumulus-oocyte complexes (COCs)}

Ovaries were obtained from Japanese black, Holstein and their crossbred cows at a local slaughterhouse in Tottori prefecture, Japan, and transported to laboratory in sterile physiological saline at $20^{\circ} \mathrm{C}$ within $4-5 \mathrm{~h}$. The COCs were collected from follicles ( 2 to $8 \mathrm{~mm}$ in diameter) by aspiration using an 18-gauge needle attached to a $10 \mathrm{~mL}$ syringe and washed with HEPES-buffered medium 199 (31100035, Gibco, Grand Island, NY, USA). Intact COCs (normal oocytes with ooplasm $>120 \mu \mathrm{m}$ in diameter and surrounded with more than three layers of unexpanded cumulus cells) were selected under a stereomicroscope (SMZ 645-3, Nikon, Japan) and used for further experiment.

\subsection{IVM}

Medium 199 Earle's salts (12340-030, Gibco) supplemented with $10 \%(v / v)$ fetal bovine serum (FBS, 26140087 , Life Technologies) inactivated at $56^{\circ} \mathrm{C}$ for $30 \mathrm{~min}$, $0.2 \mathrm{mM}$ sodium pyruvate (P5280, Sigma-Aldrich, St. Louis, MO, USA), $50 \mu \mathrm{g} \mathrm{mL}^{-1}$ gentamicin sulfate (G3632, SigmaAldrich) and $20 \mu \mathrm{g} \mathrm{mL}^{-1}$ FSH from porcine pituitary (F2293, Sigma-Aldrich) was used as a basal medium for IVM. Thirty COCs were cultured in $300 \mu \mathrm{L}$ of IVM medium supplemented with steroid hormone in a well of a 48 -well dish (150687, Thermo Fisher Scientific, USA) for $22 \mathrm{~h}$ at $39^{\circ} \mathrm{C}$ in a humidified atmosphere of $5 \% \mathrm{CO}_{2}$ in air.

\subsection{In vitro fertilization (IVF) and in vitro culture (IVC)}

Frozen-thawed semen from a Japanese black bull was used for IVF. The motile sperm were separated by centrifugation through a percoll gradient as described previously (Takahashi et al., 1996). Briefly, percoll (Pharmacia BioProcess, Uppsala, Sweden) was diluted to 45 and $90 \%(v / v)$ with modified Brackett and Oliphant isotonic medium (Brackett and Oliphant, 1975) without bovine serum albumin (BSA, BO medium), and the $2 \mathrm{~mL}$ of $90 \%$ percoll solution were overlaid with $2 \mathrm{~mL}$ of $45 \%$ percoll solution (two-layer percoll gradient). Frozen-thawed semen was placed on top of the percoll gradient and centrifuged at $700 \times g$ for $20 \mathrm{~min}$. The top layers were removed and remaining sperm pellet (at the bottom of the $90 \%$ percoll solution) was washed using BO medium by centrifugation at $500 \times g$ for $5 \mathrm{~min}$. The sperm pellet was resuspended in the same medium to yield a concentration $10 \times 10^{6}$ sperm $\mathrm{mL}^{-1}$. A $50 \mu \mathrm{L}$ sperm suspension was added to the $50 \mu \mathrm{L}$ droplet of BO medium supplemented with $6 \mathrm{mg} \mathrm{mL}^{-1}$ BSA (A6003, Sigma-Aldrich) and $5 \mathrm{mM}$ theophylline (T1633, Sigma-Aldrich). After IVM culture, 10 to 15 COCs were co-incubated with sperm $\left(5 \times 10^{6}\right.$ sperm $\left.\mathrm{mL}^{-1}\right)$ in a $100 \mu \mathrm{L}$ droplet of BO medium containing $3 \mathrm{mg} \mathrm{mL}^{-1} \mathrm{BSA}$ and $2.5 \mathrm{mM}$ theophylline cov- 
ered with liquid paraffin for $18 \mathrm{~h}$ at $39^{\circ} \mathrm{C}$ in a humidified atmosphere of $5 \% \mathrm{CO}_{2}$ in air.

After insemination, the cumulus cells were removed from oocytes by vortexing in $\mathrm{BO}$ medium and washed three times in $100 \mu \mathrm{L}$ of IVC medium that is a modified synthetic oviduct fluid with $3 \mathrm{mg} \mathrm{mL}^{-1}$ BSA instead of polyvinyl alcohol (Takahashi et al., 1996). The embryos were cultured for $192 \mathrm{~h}$ ( 8 days after start of IVF culture) in groups of 10 to 15 presumptive zygotes per $40 \mu \mathrm{L}$ droplet of IVC medium covered with liquid paraffin at $39{ }^{\circ} \mathrm{C}$ in a humidified atmosphere of $5 \% \mathrm{CO}_{2}, 5 \% \mathrm{O}_{2}$ and $90 \% \mathrm{~N}_{2}$.

\subsection{Examination of embryo development}

At $48 \mathrm{~h}$ after insemination (day 2 of IVC), cleavage rate of embryos was examined by observation of the embryos under a stereomicroscope. Developmental competence to blastocyst was evaluated at $192 \mathrm{~h}$ after insemination (day 8 of IVC). The embryos that formed blastocoele were classified into early blastocyst, blastocyst, expanded blastocyst and hatched blastocyst (Linder and Wight, 1983). The total cell number of blastocysts was counted using the air-drying method (Takahashi and First, 1992). Briefly, blastocysts were placed in a hypotonic solution $(0.9 \%$ sodium citrate supplemented with $0.3 \% \mathrm{FBS}$ ) for $15 \mathrm{~min}$. They were then treated with fixative (methanol : acetic acid =3:1) and dried on a glass slide. After staining with $3 \%$ Giemsa solution, the total cell number of each blastocyst was counted under a bright-field microscope (CX41, Nikon).

\subsection{Experimental design}

The IVM basal medium supplemented with $1000 \mathrm{ng} \mathrm{mL}^{-1}$ $\mathrm{E}_{2}$ (E8875, Sigma-Aldrich) was used as control medium (Fukui et al., 1982; Fukushima and Fukui, 1985; Younis et al., 1989; Beker et al., 2002). The COCs were cultured in the control medium for $22 \mathrm{~h}$ (control group). To imitate temporal change of $\mathrm{E}_{2}$ and $\mathrm{P}_{4}$ concentrations in bovine follicular fluid corresponding to 3 to $25 \mathrm{~h}$ after $\mathrm{LH}$ surge, the COCs were cultured in the basal medium containing $700 \mathrm{ng} \mathrm{mL}^{-1}$ $\mathrm{E}_{2}$ and $50 \mathrm{ng} \mathrm{mL}^{-1} \mathrm{P}_{4}$ (P8783, Sigma-Aldrich) for $5 \mathrm{~h}$, then moved to fresh medium containing $150 \mathrm{ng} \mathrm{mL}^{-1} \mathrm{E}_{2}$ and $150 \mathrm{ng} \mathrm{mL}^{-1} \mathrm{P}_{4}$ and cultured for $11 \mathrm{~h}$. Finally, the COCs were moved to fresh medium containing $20 \mathrm{ng} \mathrm{mL}^{-1} \mathrm{E}_{2}$ and $300 \mathrm{ng} \mathrm{mL}^{-1} \mathrm{P}_{4}$ and cultured for $6 \mathrm{~h}$ (EP group). To imitate temporal change of only $\mathrm{E}_{2}$ concentrations in the follicular fluid, the COCs were cultured in the medium containing $700 \mathrm{ng} \mathrm{mL}^{-1} \mathrm{E}_{2}$ for $5 \mathrm{~h}$, followed by the medium containing $150 \mathrm{ng} \mathrm{mL}^{-1} \mathrm{E}_{2}$ for $11 \mathrm{~h}$, and then the medium containing $20 \mathrm{ng} \mathrm{mL}^{-1} \mathrm{E}_{2}$ for $6 \mathrm{~h}$ (E group). To imitate temporal change of only $\mathrm{P}_{4}$ concentrations in the follicular fluid, the COCs were cultured in the medium containing $50 \mathrm{ng} \mathrm{mL}^{-1}$ $\mathrm{P}_{4}$ for $5 \mathrm{~h}$, followed by the medium containing $150 \mathrm{ng} \mathrm{mL}^{-1}$ $\mathrm{P}_{4}$ for $11 \mathrm{~h}$, and then the medium containing $300 \mathrm{ng} \mathrm{mL}^{-1} \mathrm{P}_{4}$ for $6 \mathrm{~h}$ (P group). These three-step IVM culture systems are
Table 1. Three-step IVM culture of bovine oocytes.

\begin{tabular}{lcrrr}
\hline \multirow{2}{*}{$\begin{array}{l}\text { Experimental } \\
\text { groups }\end{array}$} & $\begin{array}{c}\text { Steroid } \\
\text { hormones }\end{array}$ & $\begin{array}{c}\text { Concentration of steroid } \\
\text { hormones at each time of } \\
\text { IVM culture }\left(\mathrm{ng} \mathrm{mL}^{-1}\right)\end{array}$ \\
\cline { 2 - 5 } Control & $\mathrm{E}_{2}$ & 1000 & 1000 & 1000 \\
& $\mathrm{P}_{4}$ & 0 & 0 & 0 \\
\hline EP & $\mathrm{E}_{2}$ & 700 & 150 & 20 \\
& $\mathrm{P}_{4}$ & 50 & 150 & 300 \\
\hline E & $\mathrm{E}_{2}$ & 700 & 150 & 20 \\
& $\mathrm{P}_{4}$ & 0 & 0 & 0 \\
\hline $\mathrm{P}$ & $\mathrm{E}_{2}$ & 0 & 0 & 0 \\
& $\mathrm{P}_{4}$ & 50 & 150 & 300 \\
\hline
\end{tabular}

Periods of IVM culture at $0-5,5-16$ and $16-22 \mathrm{~h}$ correspond to $22-17,17-6$ and $6-0 \mathrm{~h}$ before ovulation, respectively. IVM medium was exchanged at $5 \mathrm{~h}$ and $16 \mathrm{~h}$ of IVM culture.

shown in Table 1 . In preliminary experiment using the control medium, medium exchange at 5 and $16 \mathrm{~h}$ of IVM culture did not affect subsequent embryo development to blastocysts. After IVM culture, the COCs were further cultured for IVF and IVC. The cleavage rate, blastocyst formation rate and total cell number of blastocysts were examined.

\subsection{Statistical analysis}

Experiments were replicated five times. Values are presented as means \pm standard deviation (SD). Statistical analysis was performed using StatView software (Abacus Concepts, Berkeley, CA, USA). The data of cleavage rate and blastocyst formation rate were arcsine-transformed before the analysis. The data were analyzed by one-way ANOVA followed by the Bonferroni post hoc test. Difference with $P<0.05$ was considered significant.

\section{Results}

The results of IVF-IVC after three-step IVM culture of bovine oocytes with various concentrations of $\mathrm{E}_{2}$ and $\mathrm{P}_{4}$ are shown in Table 2. At $48 \mathrm{~h}$ after insemination (day 2), the cleavage rate of embryos was not different among the groups. At $192 \mathrm{~h}$ after insemination (day 8), the blastocyst formation rate of EP group was higher than that of the other groups $(P<0.05)$. The blastocyst formation rate was not different among E, P and control groups. Percentages of early blastocyst, blastocyst, expanded blastocyst and hatched blastocyst were similar between EP and control groups. The percentage of embryos reaching the early blastocyst stage tended to be higher in E group without significant differences, while the percentage of embryos reaching the hatched blastocyst stage was highest in $\mathrm{P}$ group and significantly higher than $\mathrm{E}$ 
Table 2. The effect of three-step IVM culture imitating temporal changes of $\mathrm{E}_{2}$ and $\mathrm{P}_{4}$ concentrations in preovulatory follicles on in vitro maturational and developmental competence of bovine oocytes.

\begin{tabular}{|c|c|c|c|c|c|c|c|c|c|}
\hline \multirow[t]{2}{*}{$\begin{array}{l}\text { Experimental } \\
\text { groups }\end{array}$} & \multirow[t]{2}{*}{$\begin{array}{l}\text { Total number } \\
\text { of oocytes } \\
\text { cultured for IVC }\end{array}$} & \multirow[t]{2}{*}{$\begin{array}{l}\text { Cleavage } \\
\operatorname{rate}^{1}(\%)\end{array}$} & \multirow[t]{2}{*}{$\begin{array}{l}\text { Blastocyst } \\
\operatorname{rate}^{2}(\%)\end{array}$} & \multicolumn{4}{|c|}{$\begin{array}{l}\text { Percentage of each blastocyst stage } \\
\quad \text { (total number of blastocyst) }\end{array}$} & \multicolumn{2}{|c|}{$\begin{array}{l}\text { Total cell number of } \\
\text { blastocysts } \text { (number of }^{\text {nustocysts examined) }}\end{array}$} \\
\hline & & & & E & B & EX & $\mathrm{H}$ & B & EX \\
\hline Control & 409 & $81.2 \pm 3.3$ & $30.8 \pm 1.8^{\mathrm{B}}$ & $\begin{array}{l}28.1 \pm 15.3 \\
\quad(34)\end{array}$ & $\begin{array}{l}19.3 \pm 12.7 \\
\quad(25)\end{array}$ & $\begin{array}{l}22.6 \pm 13.4 \\
(29)\end{array}$ & $\begin{array}{c}30.0 \pm 19.1^{\mathrm{AB}} \\
(38)\end{array}$ & $\begin{array}{l}109.2 \pm 30.4 \\
\quad(25)\end{array}$ & $\begin{array}{l}161.1 \pm 40.5 \\
(29)\end{array}$ \\
\hline EP & 147 & $83.7 \pm 6.4$ & $39.4 \pm 4.4^{\mathrm{A}}$ & $\begin{array}{l}32.3 \pm 17.6 \\
\quad(19)\end{array}$ & $\begin{array}{l}13.5 \pm 10.0 \\
(8)\end{array}$ & $\begin{array}{l}26.0 \pm 6.2 \\
\quad(15)\end{array}$ & $\begin{array}{c}27.8 \pm 10.3^{\mathrm{AB}} \\
(16)\end{array}$ & $\begin{array}{l}104.3 \pm 18.2 \\
\quad(8)\end{array}$ & $\begin{array}{l}166.9 \pm 36.9 \\
\quad(15)\end{array}$ \\
\hline E & 140 & $79.9 \pm 2.4$ & $30.0 \pm 2.1^{\mathrm{B}}$ & $\begin{array}{l}43.9 \pm 22.3 \\
\quad(18)\end{array}$ & $\begin{array}{l}23.3 \pm 20.8 \\
\quad(10)\end{array}$ & $\begin{array}{l}18.6 \pm 23.1 \\
\quad(8)\end{array}$ & $\begin{array}{l}13.9 \pm 12.1^{\mathrm{B}} \\
(6)\end{array}$ & $\begin{array}{l}127.8 \pm 44.6 \\
\quad(10)\end{array}$ & $\begin{array}{c}187.1 \pm 27.3 \\
(8)\end{array}$ \\
\hline $\mathrm{P}$ & 148 & $75.7 \pm 4.2$ & $29.0 \pm 2.7^{\mathrm{B}}$ & $\begin{array}{c}14.4 \pm 15.9^{\mathrm{b}} \\
(6)\end{array}$ & $\begin{array}{c}11.4 \pm 11.9^{\mathrm{b}} \\
(5)\end{array}$ & $\begin{array}{l}22.4 \pm 17.0^{\mathrm{ab}} \\
(10)\end{array}$ & $\begin{array}{c}51.7 \pm 24.4^{\mathrm{Aa}} \\
(22)\end{array}$ & $\begin{array}{l}111.8 \pm 21.4 \\
(5)\end{array}$ & $\begin{array}{l}138.5 \pm 35.4 \\
\quad(10)\end{array}$ \\
\hline
\end{tabular}

Percentage data are means $\pm \mathrm{SD}$ of five replicates. $\mathrm{E}_{2}$ and $\mathrm{P}_{4}$ concentrations in the three-step IVM culture are shown in Table $1 .{ }^{1}$ At $48 \mathrm{~h}$ after insemination (day 2 ). No. of $2-4$ cell embryos $/$ no. of oocytes cultured. 2 At $192 \mathrm{~h}$ after insemination (day 8). No. of blastocysts / no. of oocytes cultured. ${ }^{3}$ At $192 \mathrm{~h}$ after insemination (day 8). E: early blastocyst; B: blastocyst; EX: expanded blastocyst; H: hatched blastocyst. A,B Values with different superscripts within a column differ significantly $(P<0.05)$. ${ }^{\text {a,b }}$ Values with different superscripts within a row among percentages of blastocyst stages differ significantly $(P<0.05)$.

group $(P<0.05)$. The total cell number of blastocysts and expanded blastocysts did not differ among the groups.

\section{Discussion}

In the present study, we improved the developmental competence of bovine oocytes to blastocyst stage using a threestep IVM culture system imitating temporal changes of $E_{2}$ and $\mathrm{P}_{4}$ concentrations in preovulatory follicular fluid. The three-step IVM culture system imitating either $\mathrm{E}_{2}$ or $\mathrm{P}_{4}$ concentrations in preovulatory follicular fluid (E and $\mathrm{P}$ groups) did not affect oocyte development to blastocyst, so that both $\mathrm{E}_{2}$ and $\mathrm{P}_{4}$ stimulations during IVM culture are necessary for enhancement of bovine oocyte development. In porcine embryo production, Kawashima et al. (2008) developed a threestep IVM culture system to enhance the development to blastocyst stage after IVF and IVC. Porcine oocytes were precultured with FSH and $100 \mathrm{ng} \mathrm{mL}^{-1} \mathrm{E}_{2}$ for $10 \mathrm{~h}$, after which time $10 \mathrm{ng} \mathrm{mL}^{-1} \mathrm{P}_{4}$ was added for another $10 \mathrm{~h}$. After $20 \mathrm{~h}$, COCs were moved to fresh medium containing LH, EGF and $100 \mathrm{ng} \mathrm{mL}^{-1} \mathrm{P}_{4}$. Although neither anterior pituitary hormones nor growth factors were considered in the present three-step IVM culture system of bovine oocytes, both culture systems showed effectiveness of sequential stimulation of steroid hormones during IVM.

Various concentrations of $\mathrm{P}_{4}\left(50-5000 \mathrm{ng} \mathrm{mL}^{-1}\right)$ were added to bovine IVM medium (Silva and Knight, 2000; Aparicio et al., 2011; Syoji et al., 2014). IVM culture of bovine oocytes with 50 or $100 \mathrm{ng} \mathrm{mL}^{-1} \mathrm{P}_{4}$ did not affect development to the blastocyst (Aparicio et al., 2011), while that with $94 \mathrm{ng} \mathrm{mL} \mathrm{m}^{-1} \mathrm{P}_{4}$ decreased the blastocyst formation rate (Silva and Knight, 2000). In the present study, IVM culture of bovine oocytes with 50-300 $\mathrm{ng} \mathrm{mL}^{-1} \mathrm{P}_{4}$ (P group) did not affect the blastocyst formation rate. However, supplementation with 1000 or $5000 \mathrm{ng} \mathrm{mL}^{-1} \mathrm{P}_{4}$ during the last half of IVM culture increased the blastocyst formation rate of bovine oocytes (Syoji et al., 2014). Exposure of bovine oocytes to $\mathrm{P}_{4}$ at concentration in the preovulatory follicles may not affect or adversely affect the developmental competence in vitro, but $\mathrm{P}_{4}$ at extremely high concentration may enhance it. In the present study, the percentage of embryos reaching the early blastocyst stage tended to be higher in $\mathrm{E}$ group without significant differences, whereas the percentage of embryos reaching the hatched blastocyst stage was highest in $\mathrm{P}$ group and significantly higher than $\mathrm{E}$ group $(P<0.05)$. Exposure of bovine oocytes to $\mathrm{P}_{4}$ at the preovulatory level might accelerate the embryo development in vitro.

In the present study, the $\mathrm{E}_{2}+\mathrm{P}_{4}$ treatment during IVM (EP group) seems advantageous in comparison to the other treatments, because of the highest rate of blastocyst. However, the actual differences are rather small and are nearly in the range of normal blastocyst rate after IVM. These results suggest that the other system in addition to steroid hormone action exists for improving in vitro developmental competence of bovine oocytes, for example, pituitary hormone action as shown in porcine oocytes (Kawashima et al., 2008). The present results showed the highest rate of most advanced (i.e., hatched) blastocysts in $\mathrm{P}$ group. This result suggests a possibility that the additional treatment rather than steroid hormones, such as pituitary hormones, may improve the developmental rate of $\mathrm{P}_{4}$ treatment, even though the normal blastocyst rate was higher in EP group than $\mathrm{P}$ group.

Bovine COCs secreted $\mathrm{E}_{2}$ and $\mathrm{P}_{4}$ during IVM (Mingoti et al., 2002; Schoenfelder et al., 2003; Salhab et al., 2011; Blaschka et al., 2015). During IVM of bovine COCs (30 COCs $/ 300 \mu \mathrm{L}$ IVM medium) for $24 \mathrm{~h}, \mathrm{P}_{4}$ concentration in the medium significantly increased (3.3 to $10.4 \mathrm{ng} \mathrm{mL}^{-1}$ ), but $\mathrm{E}_{2}$ concentration did not change ( 52.8 to $74.7 \mathrm{pg} \mathrm{mL}^{-1}$; Blaschka et al., 2015). Therefore, the influence of $\mathrm{P}_{4}$ secreted by COCs should be considered when $\mathrm{P}_{4}$ was added to the IVM medium. However, in the present three-step IVM culture system using $20-700 \mathrm{ng} \mathrm{mL}^{-1} \mathrm{E}_{2}$ and $50-300 \mathrm{ng} \mathrm{mL}^{-1}$ $\mathrm{P}_{4}, \mathrm{E}_{2}$ and $\mathrm{P}_{4}$ secretion by bovine COCs can be ignored 
due to their small amount and removal by medium exchange twice during the culture.

Supplementation with $\mathrm{E}_{2}$ and $\mathrm{P}_{4}$ to the IVM medium affected gene expressions of proteins by combining with each receptor in the nucleus passing through a cumulus and oocyte plasma membrane (Bain et al., 2007). Beker-van Woudenberg et al. (2004) supplemented with $\mathrm{E}_{2}$-BSA conjugate, which is a non-cell-permeable $\mathrm{E}_{2}$, to the IVM medium and demonstrated that $1000 \mathrm{ng} \mathrm{mL}^{-1}(3.67 \mu \mathrm{M}) \mathrm{E}_{2}$ had detrimental effects on maturation of bovine "denuded" oocyte. Aparicio et al. (2011) reported the presence of genomic and nongenomic $\mathrm{P}_{4}$ receptors (PRs) in bovine COCs both before and after IVM. The protein expression of genomic nPR-A and nPR$\mathrm{B}$ and nongenomic $\mathrm{mPR} \alpha$ and $\mathrm{mPR} \beta$ increased in cumulus cells after IVM, whereas genomic nPR-A and nongenomic $\mathrm{mPR} \alpha$ and $\mathrm{mPR} \beta$ decreased in oocytes after IVM, indicating a different role for each receptor in bovine oocyte maturation. In the present three-step IVM culture system of bovine oocytes, $\mathrm{E}_{2}$ and $\mathrm{P}_{4}$ added to the medium may act through various receptors in cumulus cells and oocytes.

In conclusion, the present study demonstrates that threestep IVM culture system of bovine oocytes imitating temporal changes of $\mathrm{E}_{2}$ and $\mathrm{P}_{4}$ concentrations in preovulatory follicular fluid improves the developmental potential of embryos in vitro. Further experiments are needed to evaluate the effect of temporal changes of $\mathrm{E}_{2}$ and $\mathrm{P}_{4}$ concentrations on maturational mechanism in bovine oocytes.

Data availability. The original data are available upon request from the corresponding author.

Author contributions. All authors contributed to the work described in the manuscript, and all take responsibility for it. MM, $\mathrm{KS}, \mathrm{CO}$, YG and RN as co-authors made a significant contribution to the conception and design of the experiments, as well as the analysis and interpretation of the data. Moreover, MH participated in drafting the article as well as reviewing and revising it for contents.

Competing interests. The authors declare that they have no conflict of interest.

Acknowledgements. We would like to thank staff of the meat inspection office in Tottori prefecture for collection of bovine ovaries. We thank staff of the livestock experimental station in Tottori prefecture for provision of bovine frozen semen. We also thank Shambhu Shah for English proofreading of the manuscript.

Edited by: Manfred Mielenz

Reviewed by: two anonymous referees

\section{References}

Albuz, F. K., Sasseville, M., Lane, M., Armstrong, D. T., Thompson, J. G., and Gilchrist, R. B.: Simulated physiological oocyte maturation (SPOM): a novel in vitro maturation system that substantially improves embryo yield and pregnancy outcomes, Hum. Reprod., 25, 2999-3011, https://doi.org/10.1093/humrep/deq246, 2010.

Aparicio, I. M., Garcia-Herreros, M., O’Shea, L. C., Hensey, C., Lonergan, P., and Fair, T.: Expression, regulation, and function of progesterone receptors in bovine cumulus oocyte complexes during in vitro maturation, Biol. Reprod., 84, 910-921, https://doi.org/10.1095/biolreprod.110.087411, 2011.

Bain, D. L., Heneghan, A. F., Connaghan-Jones, K. D., and Miura, M. T.: Nuclear receptor structure: implications for function, Annu. Rev. Physiol., 69, 201-220, https://doi.org/10.1146/annurev.physiol.69.031905.160308, 2007.

Beker, A. R., Colenbrander, B., and Bevers, M. M.: Effect of $17 \beta$-estradiol on the in vitro maturation of bovine oocytes, Theriogenology, 58, 1663-1673, https://doi.org/10.1016/S0093691X(02)01082-8, 2002.

Beker-van Woudenberg, A. R., van Tol, H. T., Roelen, B. A., Colenbrander, B., and Bevers, M. M.: Estradiol and its membrane-impermeable conjugate (estradiol-bovine serum albumin) during in vitro maturation of bovine oocytes: effects on nuclear and cytoplasmic maturation, cytoskeleton, and embryo quality, Biol. Reprod., 70, 1465-1474, https://doi.org/10.1095/biolreprod.103.025684, 2004.

Blaschka, C., Stinshoff, H., Poppicht, F., and Wrenzycki, C.: Temporal pattern of steroid hormone concentrations in medium used for IVM of bovine oocytes, Reprod. Dom. Anim., 50, 23-24 (abstr.), https://doi.org/10.1071/RDv27n1Ab275, 2015.

Brackett, B. G. and Oliphant, G.: Capacitation of rabbit spermatozoa in vitro, Biol. Reprod., 12, 260-274, 1975.

Dieleman, S. J., Kruip, T. A., Fontijne, P., Jong, W. H., and Weyden, G. C.: Changes in oestradiol, progesterone and testosterone concentrations in follicular fluid and in the micromorphology of preovulatory bovine follicles relative to the peak of luteinizing hormone, J. Endocrinol., 97, 31-42, https://doi.org/10.1677/joe.0.0970031, 1983.

Fortune, J. E. and Hansel, W.: Concentrations of steroids and gonadotropins in follicular fluid from normal heifers and heifers primed for superovulation, Biol. Reprod., 32, 1069-1079, 1985.

Fortune, J. E., Willis, E. L., Bridges, P. J., and Yang, C. S.: The periovulatory period in cattle: progesterone, prostaglandins, oxytocin and ADAMTS proteases, Anim. Reprod., 6, 60-71, 2009.

Fukui, Y., Fukushima, M., Terawaki, Y., and Ono, H.: Effect of gonadotropins, steroids and culture media on bovine oocyte maturation in vitro, Theriogenology, 18, 161-175, https://doi.org/10.1016/0093-691X(82)90100-5, 1982.

Fukushima, M. and Fukui, Y.: Effects of gonadotropins and steroids on the subsequent fertilizability of extrafollicular bovine oocytes cultured in vitro, Anim. Reprod. Sci., 9, 323-332, https://doi.org/10.1016/0378-4320(85)90061-2, 1985. 
Guimarães, A. L., Pereira, S. A., Leme, L. O., and Dode, M. A.: Evaluation of the simulated physiological oocyte maturation system for improving bovine in vitro embryo production, Theriogenology, 83, 52-57, https://doi.org/10.1016/j.theriogenology.2014.07.042, 2015.

Hansen, T. R., Randel, R. D., and Welsh, T. H.: Granulosa cell steroidogenesis and follicular fluid steroid concentrations after the onset of oestrus in cows, J. Reprod. Fertil., 84, 409-416, https://doi.org/10.1530/jrf.0.0840409, 1988.

Hashimoto, S., Minami, N., Takakura, R., Yamada, M., Imai, H., and Kashima, N.: Low oxygen tension during in vitro maturation is beneficial for supporting the subsequent development of bovine cumulus-oocyte complexes, Mol. Reprod. Dev., 57, 353360, 2000.

Kawashima, I., Okazaki, T., Noma, N., Nishibori, M., Yamashita, Y., and Shimada, M.: Sequential exposure of porcine cumulus cells to FSH and/or LH is critical for appropriate expression of steroidogenic and ovulation-related genes that impact oocyte maturation in vivo and in vitro, Reproduction, 136, 9-21, https://doi.org/10.1530/REP-08-0074, 2008.

Kim, J. H., Niwa, K., Lim, J. M., and Okuda, K.: Effects of phosphate, energy substrates, and amino-acids on development of in vitro-matured, in vitro-fertilized bovine oocytes in a chemically defined, protein-free culture-medium, Biol. Reprod., 48, 13201325, https://doi.org/10.1095/biolreprod48.6.1320, 1993.

Leibfried-Rutledge, M. L., Critser, E. S., Eyestone, W. H., Northey, D. L., and First, N. L.: Development potential of bovine oocytes matured in vitro or in vivo, Biol. Reprod., 36, 376-383, https://doi.org/10.1095/biolreprod36.2.376, 1987.

Lenz, R. W., Ball, G. D., Leibfried, M. L., Ax, R. L., and First, N. L.: In vitro maturation and fertilization of bovine oocytes are temperature-dependent processes, Biol. Reprod., 29, 173-179, https://doi.org/10.1095/biolreprod29.1.173, 1983.

Li, Q., Jimenez-Krassel, F., Bettegowda, A., Ireland, J. J., and Smith, G. W.: Evidence that the preovulatory rise in intrafollicular progesterone may not be required for ovulation in cattle, J. Endocrinol., 192, 473-483, https://doi.org/10.1677/JOE06-0020, 2007.

Linder, G.M. and Wight, R.W. Jr.: Bovine embryo morphology and evaluation, Theriogenology, 20, 407-416, https://doi.org/10.1016/0093-691X(83)90201-7, 1983.

Mingoti, G. Z., Garcia, J. M., and Rosa-e-Silva, A. A.: Steroidogenesis in cumulus cells of bovine cumulus-oocytecomplexes matured in vitro with BSA and different concentrations of steroids, Anim. Reprod. Sci., 69, 175-186, https://doi.org/10.1016/S0378-4320(01)00187-7, 2002.
Moor, R. M., Polge, C., and Willadsen, S. M.: Effect of follicular steroids on the maturation and fertilization of mammalian oocytes, J. Embryol. Exp. Morphol., 56, 319-335, 1980.

Rizos, D., Ward, F., Duffy, P., Boland, M. P., and Lonergan P.: Consequences of bovine oocyte maturation, fertilization or early embryo development in vitro versus in vivo: Implications for blastocyst yield and blastocyst quality, Mol. Reprod. Dev., 61, 234248, https://doi.org/10.1002/mrd.1153, 2002.

Salhab, M., Tosca, L., Cabau, C., Papillier, P., Perreau, C., Dupont, J., Mermillod, P., and Uzbekova, S.: Kinetics of gene expression and signaling in bovine cumulus cells throughout IVM in different mediums in relation to oocyte developmental competence, cumulus apoptosis and progesterone secretion, Theriogenology, 75, 90-104, https://doi.org/10.1016/j.theriogenology.2010.07.014, 2011.

Schoenfelder, M., Schams, D., and Einspanier, R.: Steroidogenesis during in vitro maturation of bovine cumulus oocyte complexes and possible effects of tri-butyltin on granulosa cells, J. Steroid Biochem. Mol. Biol., 84, 291-300, https://doi.org/10.1016/S0960-0760(03)00042-6, 2003.

Silva, C. C. and Knight, P. G.: Effects of androgens, progesterone and their antagonists on the developmental competence of in vitro matured bovine oocytes, J. Reprod. Fertil., 119, 261-269, https://doi.org/10.1530/jrf.0.1190261, 2000.

Syoji, K., Imai, K., Koyama, H., and Dochi, O.: Effect of progesterone supplementation of maturation medium on the development of in vitro-matured-in vitro-fertilized-in vitrocultured bovine embryos, Reprod. Fertil. Dev., 26, 180 (abstr.), https://doi.org/10.1071/RDv26n1Ab133, 2014.

Takahashi, Y. and First, N. L.: In vitro development of bovine one-cell embryos: Influence of glucose, lactate, pyruvate, amino acids and vitamins, Theriogenology, 37, 963-978, https://doi.org/10.1016/0093-691X(92)90096-A, 1992.

Takahashi, Y., Hishinuma, M., Matsui, M., Tanaka, H., and Kanagawa, H.: Development of in vitro matured/fertilized bovine embryos in a chemically defined medium: influence of oxygen concentration in the gas atmosphere, J. Vet. Med. Sci., 58, 897-902, https://doi.org/10.1292/jvms.58.897, 1996.

Wrenzycki, C. and Stinshoff, H.: Maturation environment and impact on subsequent developmental competence of bovine oocytes, Reprod. Dom. Anim., 48, 38-43, https://doi.org/10.1111/rda.12204, 2013.

Younis, A. I., Brackett, B. G., and Fayrer-Hosken, R. A.: Influence of serum and hormones on bovine oocyte maturation and fertilization in vitro, Gamete Res., 23, 189-201, https://doi.org/10.1002/mrd.1120230206, 1989. 